Acta vet. scand. $1978,19,561-568$.

From the Department of Pharmacology and Toxicology, Veterinary College of Norway, Oslo.

\title{
EFFECTS OF DAILY ORAL ADMINISTRATION OF COPPER TO GOATS
}

By

Nils E. Sфli and Inger Nafstad

SØLI, N. E. and I. NAFSTAD: Effects of daily oral administration of copper to goats. Acta vet. scand. $1978,19,561-568$. - Three goats were dosed orally with a $0.2 \%$ aqueous copper sulphate solution. The dosing was $20 \mathrm{mg}$ copper sulphate/ $\mathrm{kg}$ body weight twice a day for 56 to 113 days. One of the goats accumulated substantial amounts of copper in the liver and developed two haemolytic crises. The two other goats showed only increased liver copper concentrations before they were killed. The results indicate that the goats were susceptible in varying degrees to repeated oral copper dosing, and that two of the goats were significantly less susceptible to copper than sheep. The goat that turned into a haemolytic crisis showed changes similar to those seen in sheep as far as blood and plasma parameters are concerned. The gross and histological lesions were also mainly of the same type as described in sheep. The hepatic lesions found in the goat differed to some degree from those found in sheep as the necroses were more distinctly located to the centrilobular area, and as the iron pigments were mainly located in phagocytes in the hepatic sinusoides.

chronic copper poisoning; goat.

Chronic copper poisoning, being a rather common poisoning in sheep, seems to be extremely rare in goats.

Wasfi \& Adam (1976) showed that the administration of small amounts of copper sulphate intravenously to goats caused signs and lesions of acute copper poisoning. In a recent paper Adam et al. (1977) reported data concerning experimental chronic copper poisoning in goats.

The present experiment was carried out in order to compare the effects of repeated oral administration of copper to goats with our experimental data from sheep. The effects demonstrated by morphological and some clinical and chemical observations are reported. 


\section{MATERIALS AND METHODS}

Three one-year old goats (Nos. 1-3) of Norwegian breed were dosed orally with a $0.2 \%$ aqueous copper sulphate solution $\left(\mathrm{CuSO}_{4} \cdot 5 \mathrm{H}_{2} \mathrm{O}\right.$ p.a. Merck Darmstadt), as a drench six days a week. The dosing was $20 \mathrm{mg}$ copper sulphate/ $\mathrm{kg}$ body weight twice a day. The treatment was stopped when clinical signs appeared. The animals were fed on hay and concentrates and kept in indoor pens. Blood samples were drawn at weekly intervals during the accumulation period and with a few hours' intervals during the haemolytic crisis.

Haemoglobin, haematocrit, red blood cell and white cell counts, intravital staining for Heinz bodies, methaemoglobin in erythrocytes, analyses for plasma bilirubin and glutamic oxaloacetic transaminase(GOT), histological examinations and copper analyses were performed according to methods given previously (Sфli \& Nafstad 1976, Sфli \& Frøslie 1977).

\section{Clinical findings}

\section{RESULTS}

One of the goats accumulated substantial amounts of copper in the liver and developed increased plasma copper, methaemoglobinaemia and haemolysis after 56 days of dosing. The goat recovered but died due to a second crisis one month later. Copper dosing was not done during the period between the two crises. The two other goats developed only increased liver copper concentrations before they were killed after 73 and 113 days of dosing. Summarized data on the experiment are given in Table 1.

Goat No. 1 turned into the first haemolytic crisis after 56 days of dosing. There was only a slight increase in plasma copper concentrations ( $u p$ to $2.2 \mu \mathrm{g} / \mathrm{ml}$ ), but the increase might have been greater because no blood sample was drawn the day before the crisis was diagnosed. Haematocrit dropped from 40 to $15 \%$ during three days following the appearance of clinical signs. Methaemoglobinaemia occurred from the first day, the methaemoglobin concentrations in erythrocytes increased to $28 \%$ as a maximum on the second day after the crisis was diagnosed and fell to $10 \%$ on the fourth day. On the fifth day no significant increment of methaemoglobin could be measured neither in erythrocytes nor in the plasma. In the first part of the accumulation period GOT activities and bilirubin values for goat No. 1 were found to be within normal ranges (60 to 100 Sigma-Frankel 
T a b le 1. Body weight, sex, dosing programme and post-mortem concentrations of copper in liver and kidney cortex of the goats.

\begin{tabular}{|c|c|c|c|c|c|c|c|}
\hline \multirow[t]{2}{*}{$\begin{array}{l}\text { Goat } \\
\text { No. }\end{array}$} & \multirow[t]{2}{*}{ Sex } & \multirow{2}{*}{$\begin{array}{c}\begin{array}{c}\text { Body } \\
\text { weight }\end{array} \\
\text { (kg) }\end{array}$} & \multirow{2}{*}{$\begin{array}{c}\begin{array}{c}\text { Period } \\
\text { of } \\
\text { dosing }\end{array} \\
\text { (days) }\end{array}$} & \multirow{2}{*}{$\begin{array}{c}\text { Total } \\
\text { Cu } \\
\text { dosed }\end{array}$} & \multicolumn{2}{|c|}{$\begin{array}{l}\text { Copper concentrations } \\
\text { (mg/kg wet weight) }\end{array}$} & \multirow{2}{*}{ Remarks } \\
\hline & & & & & liver & $\begin{array}{l}\text { kidney } \\
\text { cortex }\end{array}$ & \\
\hline 1 & $\mathrm{~F}$ & 41 & 56 & 24 & 1168 & 635 & $\begin{array}{l}\text { The first haemolytic } \\
\text { crisis after } 56 \text { day } \\
\text { of dosing; the second } \\
\text { crisis, in which the } \\
\text { goat died, one month } \\
\text { later }\end{array}$ \\
\hline 2 & F & 43 & 73 & 32 & 384 & 4.5 & $\begin{array}{l}\text { The goat was killed } \\
\text { at the end of the } \\
\text { dosing period }\end{array}$ \\
\hline 3 & M & 37 & 113 & 43 & 314 & 3 & $\begin{array}{l}\text { The goat was killed } \\
\text { at the end of the } \\
\text { dosing period }\end{array}$ \\
\hline
\end{tabular}

units and 0.18 to $0.25 \mathrm{mg} / 100 \mathrm{ml}$, respectively) according to Hansen (1970). One week prior to the haemolytic crisis, however, the GOT activities and the bilirubin values in plasma increased to 250 Sigma-Frankel units and $1.0 \mathrm{mg} / 100 \mathrm{ml}$, respectively. During the crisis some additional increase in both values was observed. The goat showed general depression, loss of appetite and passing of soft faeces and dark urine. The visible mucous membranes were muddy brown in colour. The goat recovered from the crisis without any therapy. Copper dosing was not done during the rest of the experimental period. GOT-activities in plasma dropped to 165 Sigma-Frankel units just after the crisis and then again started to increase slowly. Bilirubin was within normal ranges during the following month; then another crisis occurred. Plasma copper concentration increased for a second time and was measured to be $7.5 \mu \mathrm{g} / \mathrm{ml}$ at the beginning of the second crisis. Methaemoglobin concentration in erythrocytes was measured to an amount of $17 \%$ and Heinz bodies were observed in $90 \%$ of the red cells the second day of the crisis and increased to $98 \%$ on the third day. Reticulocytosis was pronounced, and ghost erythrocytes appeared in considerable numbers. GOT and bilirubin increased to 800 Sigma-Frankel units and $2.6 \mathrm{mg} / 100$ $\mathrm{ml}$, respectively, on the fourth day of crisis, which was the day of death. 
Goats Nos. 2 and 3 developed increased liver copper concentrations before they were killed after 73 and 113 days of dosing, respectively. For these two goats GOT activities and bilirubin values in plasma were within normal ranges throughout the experiment. Plasma copper concentrations were 0.9 to 1.8 and 1.1 to $1.7 \mu \mathrm{g} / \mathrm{ml}$ for goats Nos. 2 and 3 , respectively. No abnormal haematological values were recorded at any stage of the experimental period.

\section{Gross lesions}

The carcass of goat No. 1 showed a yellow-brownish colour. The liver was yellowish brown, and the kidneys were swollen, enlarged and dark coloured. The bladder contained dark coloured urine. Petechial haemorrhages were observed subepicardially. No gross lesions were seen in the other two goats.

\section{Histological findings}

The histological lesions of goat No. 1 were most evident in kidney and liver. There was an acute nephrosis mainly localized to the proximal parts of the tubuli, with epithelial cell remnants and proteinaceous masses occluding the lumina. Iron-containing pigment granula occupied the cytoplasmic space in the remaining epithelial cells. In addition, glomerular injury was pronounced, with dilation of the Bowman's capsular space containing proteinaceous exudate and desquamated cells.

In the liver, centrilobular necroses with some inflammatory reactions were observed. Iron-containing pigment within hepatocytes and Kupffer cells was scarce, while in the sinusoidal spaces numerous macrophages stuffed with iron-containing pigment granules were seen (Fig. 1). Intracellularly iron pigment was also located in the red pulp of the spleen.

The only significant finding in the other goats was the oc-

F i g u r e 1. Histological section from goat No. 1 showing centrilobular necrosis (N) with leukocytic inflammatory reaction (L). Pigmentloaded phagocytes in the sinusoids are indicated by arrows. Hatmatoxylin-eosin stain $\times 180$.

Fi g u re 2. Histological section from goat No. 2 showing necrosis of individual cells (N). Pigment-loaded phagocyte is indicated by an arrow. Haematoxylin-eosin stain $\times 180$. 


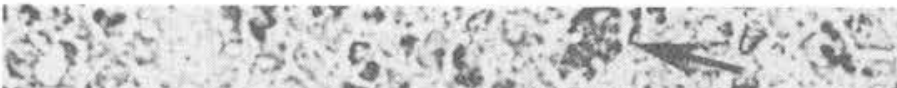

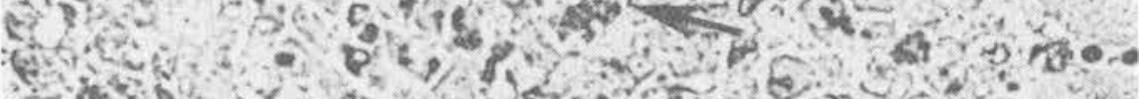
3.

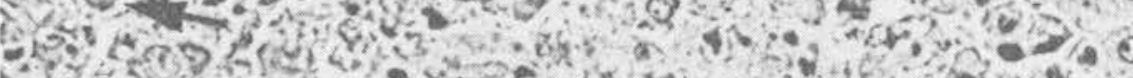

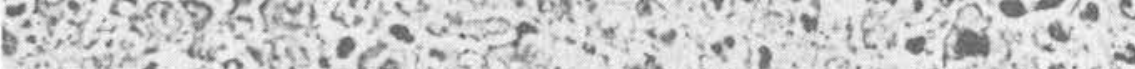

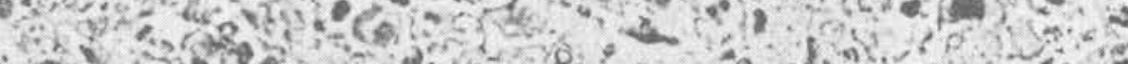

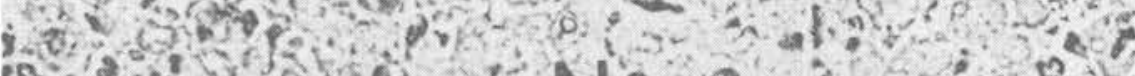

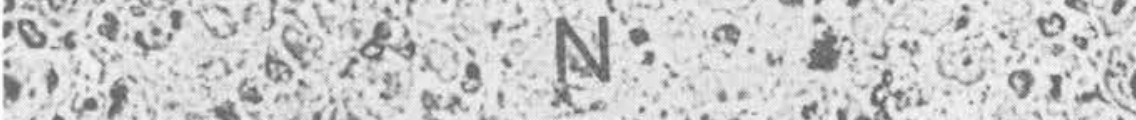

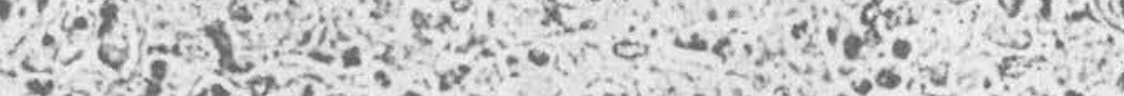

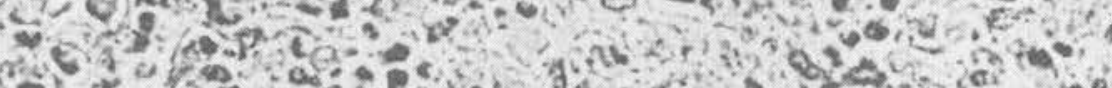

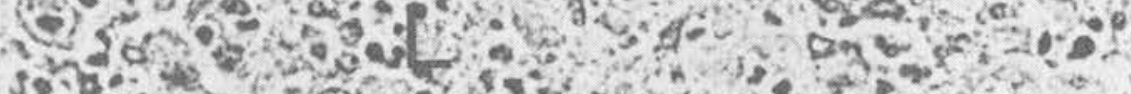

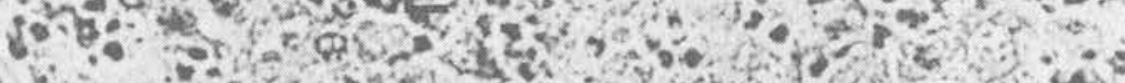

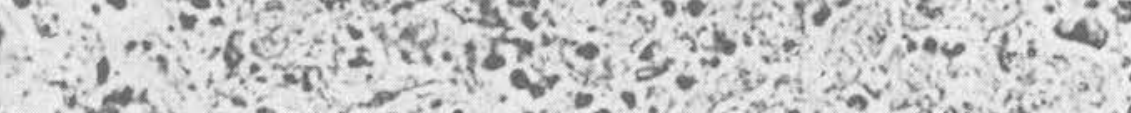

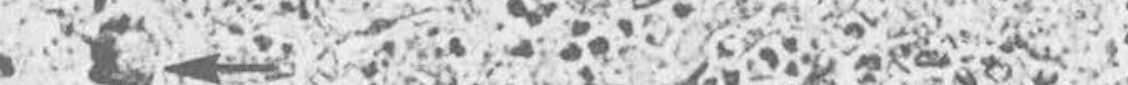

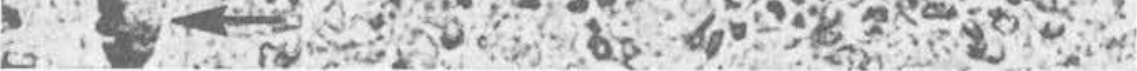

Fig. 1.

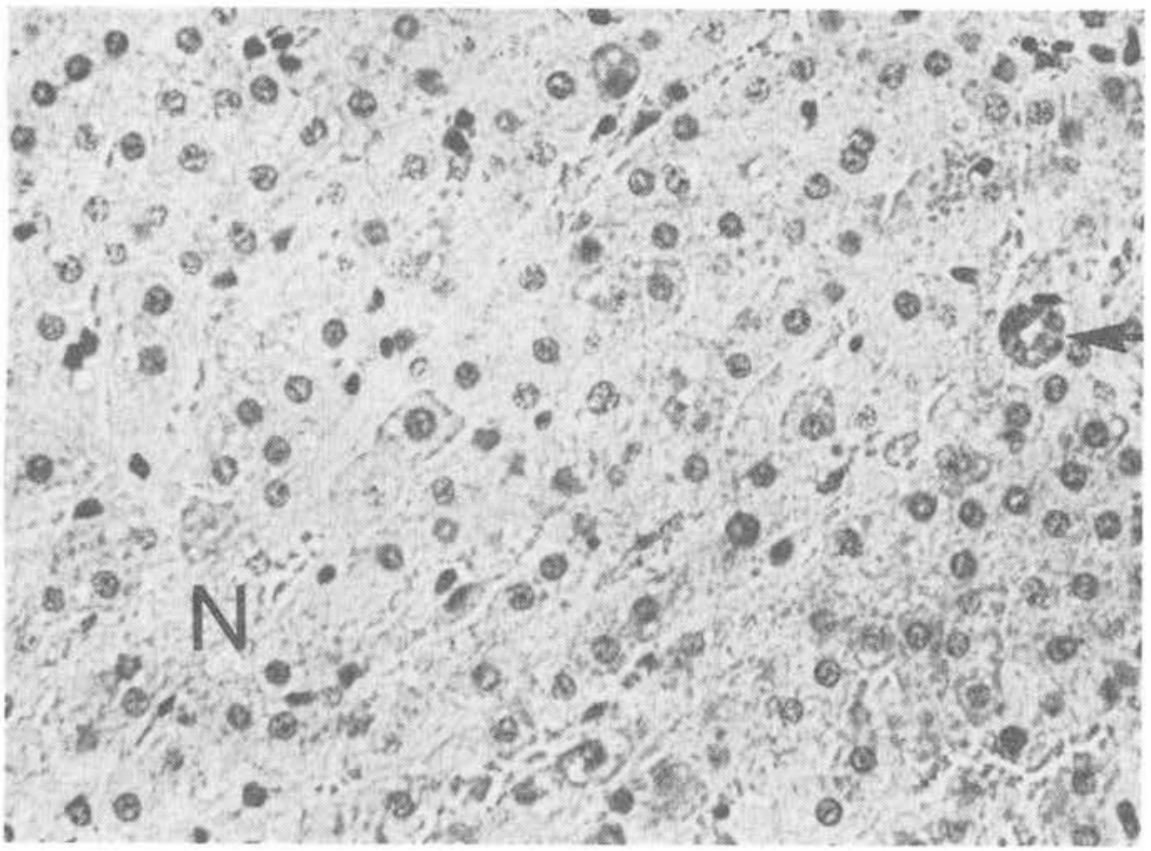

Fig. 2. 
currence of iron-containing pigment granules in sinusoidal macrophages in the liver, together with individual liver cell necroses in goat No. 2 (Fig. 2).

\section{DISCUSSION}

The results indicate that goats are susceptible in varying degrees to repeated oral copper dosing, but less so than sheep. The amount of copper administered to the goats in the present experiment was totally three to four times as high as that administered to sheep under comparable conditions (Sфli \& Fr $\phi$ slie 1977).

Only one of the goats accumulated substantial amounts of copper in the liver and developed subsequently a haemolytic crisis. The two other goats also developed increased liver copper but less so than would have been expected in sheep with the same copper dosing programme. The experiment indicates that there may be differences in the handling of copper between goats and sheep.

The goat that turned into haemolytic crisis developed pathological changes similar to those of sheep as far as blood and plasma parameters are concerned (Todd \& Thompson 1963, Ishmael et al. 1972, Sфli \& Nafstad 1976, Søli \& Fr $\phi s l i e)$.

The gross and histological lesions were predominantly of the same type as described in sheep (Nordstoga 1962, Ishmael et al. 1971, Gopinath \& McC. Howell 1975, Søli \& Nafstad). The hepatic injuries found in the goat, however, differed somewhat from those of sheep by having more distinctly location of the necroses to the centrilobular area, and by the iron pigments mainly being located to phagocytes in the hepatic sinusoides.

The morphological findings in goat No. 2 indicate that a minor episode of haemolysis might have occurred. However, this possible event was not recorded by our clinical examinations. The observation that iron-containing products were mainly located in phagocytes may indicate differences between goat and sheep in the mode of deposition of iron containing pigments following haemolysis.

The findings described in the present experiment are in accordance with those described by Adam et al. (1977) as far as susceptibility to copper, post-mortem findings and routine haematology are concerned. 


\section{ACKNOWLEDGEMENTS}

The determination of copper concentrations in plasma, liver and kidney cortex was carried out at The National Veterinary Institute, Oslo, Norway.

Transaminase and bilirubin analyses were performed at the Department of Internal Medicine I, Veterinary College of Norway, Oslo.

\section{REFERENCES}

Adam, S. E. I., I. A. Wasfi \& M. Magzoub: Chronic copper toxicity in Nubian goats. J. comp. Path. 1977, 87, 623-627.

Gopinath, C. \& J. McC. Howell: Experimental chronic copper toxicity in sheep. Changes that follow the cessation of dosing at the onset of haemolysis. Res. vet. Sci. 1975, 19, 35-43.

Hansen, M. Aas: Kliniske leverpr $\varnothing v e r$ hos drøvtyggere. (Clinical liver tests in ruminants). Thesis, Oslo $1970,255 \mathrm{pp}$.

Ishmael, J., C. Gopinath \& J. McC. Howell: Experimental chronic copper toxicity in sheep. Histological and histochemical changes during the development of the lesions in the liver. Res. vet. Sci. $1971,12,358-366$.

Ishmael, J., C. Gopinath \& J. McC. Howell: Experimental chronic copper toxicity in sheep. Biochemical and haematological studies during the development of lesions in the liver. Res. vet. Sci. $1972,13,22-29$.

Nordstoga, K.: Unders $\varnothing$ kelse over en særlig form for kopperforgiftning hos sau. (Investigation on a special kind of copper poisoning in sheep). 9th Nord. Vet. Congr., Copenhagen 1962, Proc. 196201.

Søli, N. E. \& I. Nafstad: Chronic copper poisoning in sheep. Structural changes in erythrocytes and organs. Acta vet. scand. 1976, 17, $316-327$.

Søli, N. E. \& A. Frøslie: Chronic copper poisoning in sheep. I. The relationship of methaemoglobinaemia to Heinz Body formation and haemolysis during the terminal crisis. Acta pharmacol. (Kbh.) 1977, 40, 169-177.

Todd, J. R. \& R. H. Thompson: Studies on chronic copper poisoning: II. Biochemical studies on the blood of sheep during the haemolytic crisis. Brit. vet. J. $1963,119,161-173$.

Wasfi, I. A. \& S. E. I. Adam: The effects of intravenous injection of small amounts of copper sulphate in Nubian goats. J. comp. Path. 1976, 86, 387-391.

\section{SAMMENDRAG}

Effekter av daglig oral dosering av kobber til geit.

Det ble gitt oralt $20 \mathrm{mg} \mathrm{CuSO}_{4} / \mathrm{kg}$ kroppsvekt 2 ganger daglig i 56 - 113 dager til 3 geiter. En av geitene akkumulerte betydelige mengder kobber i leveren og gjennomgikk to hemolyttiske kriser. De to andre geitene fikk moderat for $\varnothing \mathrm{kning}$ av kobberkonsentrasjonen $i$ 
leveren, men viste ingen kliniske symptomer på kobberforgiftning f $\varnothing \mathrm{r}$ de ble avlivet. Resultatene viser at geitene var følsomme overfor gjentatt oral kobberdosering i varierende grad, videre at to av geitene var betydelig mindre følsomme overfor kobber enn sau. Geita som fikk hemolyttisk krise, viste de samme forandringer som er vanlig hos sau når det gjelder blod- og plasmaparametre. Makroskopiske og histologiske forandringer var hovedsakelig av samme type som beskrevet hos sau. Forandringene i leveren hos denne geita skilte seg fra lesjonene hos sau ved at de var mer tydelig lokalisert til centrolobulære områder og ved at jernpigmenter hovedsakelig var lokalisert til fagocytter i leverens sinusoider.

(Received May 16, 1978).

Reprints may be requested from: Nils E. Søli, the Department of Pharmacology and Toxicology, Veterinary College of Norway, P.O. Box 8146, Oslo Dep., Oslo 1, Norway. 